\title{
Implemetation HOTS Based-Learning During Covid-19 Pandemic in Indonesian Elementary School
}

\author{
Annis Maulia Fatimahtuzzahroh ${ }^{1}$, Ali Mustadi ${ }^{2}$, Muhammad Nur Wangid ${ }^{3}$ \\ Postgraduate School of Basic Education, Yogyakarta State University, Indonesia \\ *Corresponding e-mail: annismaulia.2019@student.uny.ac.id
}

Received: 10 February $2021 \quad$ Accepted: 18 March $2021 \quad$ Published: 22 March 2021

Abstract: Implementation HOTS Based-Learning during Covid-19 Pandemic in Indonesian Elementary School. Objective: This research aims to describe the learning process oriented HOTs in midst of the Covid-19 pandemic outbreak. Method: This research is a qualitative research with phenomenological research type. The data was collected by phone interview to 17 elementary school teachers in Central Java Province. Data analysis is using Bogdan \& Biklen models. Findings: The results showed that the application of HOTs-based learning during pandemic: 1) teacher's knowledge of HOTS learning is quite good, 2) planning of HOTS-based learning process is still not optimal, 3) HOTs-based learning process has not been carried out to the maximum, 4) In the evaluation activities of HOTS-based learning is still relatively low , and 5) Many obstacles faced during HOTS-based learning process. Conclusion: HOTs-based learning during the Covid-19 pandemic cannot be done to the maximum although there are teachers who have tried to implement it in accordance with their knowledge.

Keywords: HOTs-based learning, Covid-19 pandemic, elementary school.

Abstrak: Penerapan Pembelajaran Berbasis HOTS Selama Pandemi Covid-19 di Sekolah Dasar Indonesia. Tujuan: Penelitian ini bertujuan untuk mendiskripsikan proses pembelajaran berorientasi HOTs di tengah wabah pandemic Covid-19. Metode: Penelitian ini merupakan penelitian kualitatif dengan jenis penelitian fenomenologi. Data dikumpulkan dengan wawancara by phone kepada 17 guru sekolah dasar di Provinsi Jawa Tengah. Analisis data yang digunakan menggunakan model Bogdan \& Biklen. Temuan: Hasil penelitian menunjukkan bahwa penerapan pembelajaran berbasis HOTs selama pandemi: 1) pengetahuan guru tentang pembelajaran HOTS cukup baik, 2) perencanaan proses pembelajaran berbasis HOTS masih belum optimal, 3) Proses pembelajaran berbasis HOTs belum terlaksana secara maksimal, 4) Pada evaluasi pembelajaran berbasis HOTS masih tergolong rendah, dan 5) Banyak kendala yang dihadapi selama pelaksanaan proses pembelajaran berbasis HOTS berlangsung. Kesimpulan: Pembelajaran berbasis HOTs di masa pandemic Covid-19 tidak dapat dilakukan secara maksimal walaupun ada guru yang sudah berusaha menerapkannya sesuai dengan pengetahuannya.

Kata kunci: pembelajaran berbasis HOTs, pandemi Covid-19, sekolah dasar.

\section{To cite this article:}

Fatimahtuzzahroh, A. M., Mustadi, A., \& Wangid, M. N. (2021). Implemetation HOTS Based-Learning During Covid-19 Pandemic in Indonesian Elementary School. Jurnal Pendidikan Progresif, 11(1), 96 -111. doi:10.23960/jpp.v11.i1.202109. 


\section{- INTRODUCTION}

Education is a very important aspect for a country. A country can be said to be a developed country because one of them is influenced by the quality of its education. Improving the quality of education is to develop students a variety of skills as an effort to prepare to encounter complex problems that arise in the future. So is the encounter of 21 st century learning. Some skills needed in learning in the 21 st century include: 1) life and career skills; 2) information, media, and technology skills and 3 ) learning and innovation skills (i.e. communication, collaboration, critical thinking, and creativity thinking) (Fadel, 2008). Learning and innovation skills in critical thinking and creative thinking are the thinking patterns needed in this 21 st century learning.

Thinking is a basic skill that students need to have to achieve their learning goals. According to Suryabrata (2015) thinking is a dynamic process that can be described according to the process consists of forming understanding, forming opinions, and drawing conclusions. Similarly, Suntrock (2011) that thinking involves manipulating and transforming information in memory to shape concepts, reasoning, critical thinking, making decisions, creative thinking, and problem solving. Thinking about something means focusing on a particular object and trying to find out information about the object which is then informed in memory. ((Cer, 2018); (Wall, 2015); and (Hassan, Rosli, \& Zakaria, 2016)) suggest that HOTS is a component of critical thinking skills and creative thinking skills.

Cer (2018) suggests that High Order Thinking Skill is a style of thinking derived from basic thinking and based on reasons involving decision-making, critical thinking, metacognitive, reflective, analytical and relational skills, creative, analyzing and synthesizing, interpreting and concluding. High
Order Thinking Skill is a slice of the cognitive dimension of Bloom's taxonomy that has been revised with three dimensions of procedural knowledge (i.e. konseptual, procedural, and metacognitive) (Anderson L. W. and Krathwohl D. R., 2001). (Saputra, 2016) states that: "HOTS is a process of thinking students at a higher cognitive level developed from several concepts and cognitive methods and learning taxonomy such as Krulik and Rudnick problem solving methods (1998); Bloom taxonomy (1956); and taxonomy of learning, teaching, and assessment from Anderson and Karthwohl (2001)". The purpose of HOTS is to improve students' skill in learning materials so that they can still and train students to think critically (critical thinking), creative thinking, able to solve problems (problem solving), and able to make decisions (making decisions) to the problems encountered.

Based on Piaget's stage of cognitive development, elementary school age students are at a concrete stage that is the child is able to think logically and rationally, such as reasoning to solve concrete problems. This shows that high order thinking skills can be instilled while they are still in elementary education. High Order Thinking Skill (HOTS) occurs when a student obtains new information, then remembers and compiles, connects with existing knowledge and generates that information to achieve a goal or problem solving (Yee et al., 2015). By the integration of existing knowledge with new information, the students will be able to analyze peer problems from various points of view

The implementation of curriculum 2013 currently emphasizes embedding and training students on HOTS skills at various levels of education. These changes are contained in the Permendikbud Nomor 22 Tahun 2016 which explains that the learning process must integrate 
with literacy, Higher Order Thinking Skills (HOTS) and 4C as challenges for the 21 stcentury learning. The implementation of hotsbased curriculum 2013 has been running for 8 years starting from 2013- now. Conklin (2012) states that there are four things teachers can do in HOTS-based learning: opening lessons with questions that lead to HOTS with start discussions and debates, placing brainstorming activities in the middle of the lesson so that students can find ideas and think creatively, ending lessons with HOTS questions that are used as assessment tools, and providing openended tasks as homework to find out their creativity and understanding of the lessons that they have learned. These four things mentioned by Conklin can be a reference for implementing HOTS-based learning in the classroom.

HOTS-based learning process emphasizes student center compared to teacher center. The understanding of this student center is that students are active in the learning process and teachers act as facilitators for students. In order to create learning that is student center is by using the learning model. The learning model is such as problem-based learning (PBL) (Yulianto, Pramudya, \& Slameet, 2019), project-based learning (PjBL) (Suherman et al., 2020), discovery learning, and inquiry-based learning ((Indah, 2020); (Riandari, Susanti, \& Suratmi, 2018); (Mubarok, Suprapto, \& Adam, 2019)),or other learning models using contextual problems. In addition, the use of learning models can make it easier for teachers to carry out the learning process so that it can run structured.

In its implementation, HOTs-based learning is still a lot of obstacles and the results fall into the category of sufficiently than expected limits. The research conducted Sofyan \& Fihtanti (2019) shows that the success rate of elementary school teachers in formulating HOTs-based learning seen from the planning is good, the implementation of learning is sufficient and the success rate in formulating authentic assessment based on HOTS category is quite good. This shows that HOTS-based learning still needs to be improved again to be able to achieve good categories even up to very good.

In addition, research conducted by Afifah \& Retnawati (2019) at the senior high school level showed that teachers still find it difficult to apply HOTS-based learning (delivering apperception, designing and applying assessment, delivering and preparing tools and materials, and making media). Teachers' knowledge about HOTS is still low. It also shows that there is still a need for teachers in schools to be guided in arranging and creating hots-based learning processes. Other research conducted by Ramdiah, Abidinsyah, Royani, \& Husamah (2019) revealed that the teacher's knowledge about HOTS is good but in its implementation is not in accordance with the understanding that has and is inconsistent in its implementation. The research conducted Anggraeni \& Sole (2020) also revealed that for elementary school teachers in one of the eastern regions of Indonesia still do not understand and are not able to define HOTSbased learning. Based on previous research, it can be concluded that the learning process based on HOTS both in elementary school and senior high school still needs to be improved again. Especially the provision of socialization and training for teachers in implementing HOTS-based learning.

On the other hand, the world is currently encountering a case of disease outbreak, namely Covid-19. Yuliana (2020) stated that Covid-19 or Corona Virus 19 is a single positive RNA strain virus that infects the respiratory tract and is contagious. This statement is supplemented by an opinion Susilo 
et al (2020) which states that relatively rapid transmission, has a mortality rate that cannot be ignored, and the absence of definitive therapy. This kind of this situation requires that the original face-to-face learning be done by reducing face-to-face between teachers and students or known as online learning or distance learning. This is in accordance with Indonesian government regulation No. 36962 / MPK. A / HK / 2020 dated March 17, 2020 issued by the ministry of education and education about courageous education and working from home. The current Covid-19 pandemic is very influential on several education sectors, especially in the implementation of HOTS based learning.

From previous research has shown that there is still a need to improve the quality of hots based learning implementation. However, on the other hand the learning process must be limited by online learning. The existence of online learning is considered by teachers are not able to maximize learning in accordance with the expected goals. The research conducted Rahayu, Altaftazani, Kelana, Firdaus, \& Fauzi (2020) shows that mathematics learning in elementary schools during Covid-19 is in the medium category of the expected good category. But in this study explained that this medium category is not only influenced by online learning factors but also other factors (i.e characteristics, packaging of learning, environment, and teaching materials used). This situation makes teachers to be creative and work hard in managing the learning process. As a public policy, the implementation of HOTS-based learning in elementary schools during the Covid-19 pandemic in accordance with the demands of the 2013 Curriculum needs to be reviewed the effectiveness of its implementation in various regions, no exception in Central Java Province. Based on this background, this article will describe the HOTs-based learning process implemented during the Covid-19 Pandemic. This aims to obtain accurate data and information related to the implementation of HOTS-based learning at the elementary school level during the Covid-19 pandemic.

\section{- METHOD \\ Types of Research}

This research is a qualitative study in phenomenological approach. This study aims to explore the implementation of hots-based learning of elementary schools in Central Java Province during the Covid-19 Pandemic.

\section{Research Participation}

The study participants were teachers from 17 elementary schools (T1-T17) in Central Java Province from 14 districts involving Kebumen, Purworejo, Magelang, Klaten, Pati, Sragen, Boyolali, Surakarta City, Salatiga, Purbalingga, Sukoharjo, Temanggung, Batang and Kudus. Participants are selected randomly. The object research is social condition and conditional learning interaction that attracts the implementation of elementary school HOTs-based learning during the Covid19 Pandemic.

\section{Instrument and Procedure}

Data collection in the field using FGD and telephone interviews. FGD topics and interviews consist of five sub-themes: 1) teacher knowledge about HOTS, 2) HOTs-based learning planning, 3) implementation of HOTsbased learning, 4) evaluation of HOTs-based learning, and 5) resistance to HOTs-based learning during the Covid-19 Pandemic.

\section{Data Analysis}

Data from FGD and interviews are analyzed and presented in tables to be classified into sub-themes. Data analysis from FGD involves Bogdan and Biklen models (1982) to find out the relationship between sub themes. 
On the other hand, analysis of teachers' answers to HOTS problem solving involves descriptive analysis. At the beginning of the FGD and interviews, researchers informed participants that the study would only capture their knowledge of HOTS and its teaching and learning strategies. Interviews are naturally conducted to obtain credible information. Teacher names are retained and for research purposes, their identities are encoded to ensure their answers have no effect on their profession as teachers.

\section{RESULTS AND DISCUSSION}

One of the components of implementing the 2013 curriculum in Indonesia is an integrating high order thinking skills (HOTs) in learning. HOTS is part of Taxonomy Bloom's revised cognitive domain category consisting of three-dimensional processes (analysis, evaluation, and creation) with components of knowledge dimensions (conceptual, procedural, and metacognitive) (Anderson L. W. and Krathwohl D. R., 2001). The implementation of HOTS in learning is inseparable from the teacher's understanding of HOTS itself. Based on previous research, HOTS-based learning can't be said to be maximal. Meanwhile, the implementation of education is disrupted due to Covid-19. This is a challenge for teachers in implementing HOTS-based learning in the midst of the Covid-19 pandemic.

The results provide information about teachers' perception of the implementation of learning-based HOTs during Covid-19. Teachers' perceptions are classified into teacher knowledge about HOTS, HOTs-based learning planning, HOTs-based learning implementation, HOTs-based learning evaluation, and 5) HOTs-based learning resistance during the Covid-19 Pandemic. Researchers explain each sub-theme below.

\section{Teacher's Knowledge of HOTS}

The results of data analysis and teacher knowledge about HOTS show that their knowledge of HOTS is quite good. The results can be seen in Table 1. These findings suggest that teachers have described HOTS-based learning using Bloom's three revised taxonomy levels (analyzing, evaluating, and creating), learning that invites students to think critically, creatively, logically, and metacognitive. However, there are some teachers who have not been able to explain in detail what kind of learning is based on HOTs. Some of them simply explain that HOTs-based learning is a skill-oriented learning level without understanding the form of HOTSbased learning. Based on FGD results, new teachers are able to understand conceptual knowledge, but cannot explain operational knowledge properly. Based on the teacher's response, not all teachers understand HOTS well.

The results of this study indicate that teachers' knowledge of HOTS is quite good. However, teachers do not yet fully understand HOTS-based learning. Some understand it as high skill-oriented learning without understanding the form of hots learning process, the form of assessment used. The other teachers were only able to explain the focus of hots assessment form in the form of cognitive assessment C4-C6 (T1 and T17). As for being able to lead students to work on HOTS problems, teachers need to experience HOTS-based learning. Similarly, in the preparation of HOTS-based questions are not only limited to the C4-C6 level, but contain conceptual, procedural, or metacognitive knowledge. Further interviews showed that some of the teachers felt they were not familiar with the correct form of HOTS-based learning process so that they tried to implement HOTs-based learning according to what theyknew. Retnawati(2016)also stated that teachers' trainings and Curriculum 2013 socialization in Indonesia are still insufficient. This signifies the need for the Government to provide socialization and training to teachers equally. 
Table.1 Master's Knowledge of HOTS oriented learning

\begin{tabular}{ll}
\hline Teachers' Knowledge about HOTS-oriented learning & Verification Result \\
$\begin{array}{ll}\text { Higher Order Thinking Skills (HOTS) oriented learning is usually } \\
\text { problem-based learning. I'm not going to say that. }\end{array}$ & $\begin{array}{l}\text { The teacher's knowledge of } \\
\text { HOTS-based learning is quite } \\
\text { good. Not all teachers are able to } \\
\text { explain the complete form of }\end{array}$ \\
$\begin{array}{ll}\text { HOTs learning is a way for students to have skills in solving } \\
\text { problems and critical thinking (T9) }\end{array}$ & $\begin{array}{l}\text { HOTs-based learning. } \\
\text { High-level thought-based learning, where students are trained to } \\
\text { learn independently, creatively, and have higher levels of } \\
\text { knowledge skills. I'm not going to say that. }\end{array}$ \\
$\begin{array}{ll}\text { Learning that is oriented to the high level of thinking skills of } \\
\text { learners as an effort to improve the quality of education. (T4), (T5) } \\
\text { (T6), (T7), (T8), (T10), (T12), (T14), (T16). }\end{array}$ & \\
$\begin{array}{l}\text { Critical, logical, reflective, metacognitive, and creative thinking } \\
\text { skills that are high-level thinking abilities. I'm not going to say that. }\end{array}$ & \\
$\begin{array}{l}\text { HOTs are learning that uses a high level of thinking using the } \\
\text { cognitive realm of C4 to C6. (T1), (T17) }\end{array}$ & $\begin{array}{l}\text { The process of learning by means of processing high-level skills } \\
\text { that apply exploration as the formation of thinking patterns (T3) }\end{array}$ \\
\hline
\end{tabular}

\section{Planning of HOTs-based learning}

Table 2 contains the results of data analysis and reduction from planning of HOTs-based learning during the Covid-19 Pandemic. HOTsbased learning planning consists of learning processes implemented during the Covid-19 Pandemic, teaching materials used, learning media, and learning models. The results showed that the planning of HOTS-based learning process is still not as maximum as expected. Learning is done online, home visit, even enforced face-to-face 2 or 3 times a week. The teaching materials used by teachers are using the 2013 curriculum book published by the government where this book is relevant enough to imprison HOTs. In generally, teachers use WhatsApp learning media that is then equipped with learning videos from Youtube. While the learning video from youtube is not necessarily the material delivered based on HOTs. Then for the learning model used, some teachers apply PBL and PjBL. Both learning models are learning models that support the learning process based on HOTs. However, for the design of the learning model with its application is not able to be observed directly because of limitations. The reduction results of each subtheme can be seen in the table below.

Table 2. Lesson plan of HOTs based learning

\begin{tabular}{|c|c|c|}
\hline & Planning of HOTs-based learning & Verification Result \\
\hline $\begin{array}{l}\text { Learning } \\
\text { Forms }\end{array}$ & $\begin{array}{l}\text { - Learning is carried out online and offline. For offline } \\
\text { learning is carried out in school only } 1 \text { hour. (T1), } \\
\text { (T3), (T5), (T6), } \\
\text { - Online learning via WhatsApp or google form } \\
\text { (online) and home visit when environmental } \\
\text { conditions are safe (covid } 19 \text { distribution map is } \\
\text { green) (T9), } \\
\text { - Distance Learning (PJJ) and Face-to-face are } 2 \text { to } 3 \\
\text { times a week depending on the conditions and } \\
\text { circumstances in the school environment and } \\
\text { surrounding communities. (T14). }\end{array}$ & $\begin{array}{l}\text { The learning process during the } \\
\text { Covid-19 pandemic is currently } \\
\text { carried out online and there are some } \\
\text { that also vary the learning process } \\
\text { with home visit or face-to-face week } \\
2 \text { or } 3 \text {. }\end{array}$ \\
\hline
\end{tabular}


- Learning patterns are done online through WA, voice note, video call, zoom, google form, and monitor student work when students collect assignments. (T2), (T4), (T7), (T8), (T10), (T11), (T12), (T13), (T15), (T16), (T17).

\begin{tabular}{|c|c|c|}
\hline $\begin{array}{l}\text { Teaching } \\
\text { Materials }\end{array}$ & $\begin{array}{l}\text { Stay with student books } \\
\text { Additional material from videos and articles on the } \\
\text { Internet } \\
\text { Learning modules } \\
\text { Student Worksheet }\end{array}$ & $\begin{array}{l}\text { The teaching materials used continue } \\
\text { to use the thematic books of students } \\
\text { of the } 2013 \text { curriculum from the } \\
\text { government. This book already refers } \\
\text { to HOTs-based learning. However, } \\
\text { teacher should not make this } 2013 \\
\text { curriculum book as the only book. }\end{array}$ \\
\hline $\begin{array}{l}\text { Learning } \\
\text { Media }\end{array}$ & $\begin{array}{l}\text { - Using real media during offline meetings while for } \\
\text { learning that is often used is online media namely } \\
\text { audio visual media and youtube links that share on } \\
\text { WhatsApp groups. (T1), (T3), (T5), (T9) } \\
\text { - Learning media used in the form of learning videos } \\
\text { from youtube links and objects in the neighborhood } \\
\text { around school and home. (T2), (T4), (T6), (T7), (T8), } \\
\text { (T12), (T13), (T16) } \\
\text { - during this pandemic, the media used are online } \\
\text { media (WhatsApp, Google Classroom), Youtube, } \\
\text { Quiziz, student environment. T(10), T(11), (T14), } \\
\text { (T15), (T17) }\end{array}$ & $\begin{array}{l}\text { The learning media used by teachers } \\
\text { in generally take videos from } \\
\text { youtube. While from youtube is not } \\
\text { necessarily all the material submitted } \\
\text { is able to train HOTs. Whereas in } \\
\text { fact teachers can develop HOTS- } \\
\text { based media through existing } \\
\text { educational platforms. }\end{array}$ \\
\hline $\begin{array}{l}\text { Learning } \\
\text { Models }\end{array}$ & $\begin{array}{l}\text { - The learning model used by PBL is to invite students } \\
\text { and train students to solve problems in their } \\
\text { knowledge independently. (T1), (T3), (T6) } \\
\text { - A frequently used learning model is Project Based } \\
\text { Learning because it makes it easier for students to do } \\
\text { it at home and trains students to explore their skills } \\
\text { and knowledge (T11). } \\
\text { - Learning models used by Contextual Teaching and } \\
\text { Learning (T14) } \\
\text { - Learning models used by SOLE for online and } \\
\text { offline CBSA (T13) } \\
\text { - The learning model used is Online learning (T7), } \\
\text { (T12) } \\
\text { - The learning models used are Blended (T2), (T4), } \\
\text { (T9), (T15), (T16), (T17) learning. } \\
\text { (The learning model used is Thematic learning (T5), }\end{array}$ & $\begin{array}{l}\text { Some of the teachers have } \\
\text { implemented learning that already } \\
\text { refers to HOTs-based learning, } \\
\text { namely PBL, PjBL. In addition, it } \\
\text { turns out that teachers are also still } \\
\text { able to distinguish between learning } \\
\text { models and learning methods. } \\
\text { Teachers consider online, blanded, } \\
\text { and thematic learning to be a learning } \\
\text { model }\end{array}$ \\
\hline
\end{tabular}

Even the existence of Covid-19 makes the learning process disrupted due to learning from home and done through distance learning or online. Therefore, teachers and students must adapt to a new learning environment with limited implementation of learning activities.
Like HOTS-based learning with a learning environment that usually teachers still find difficult, especially with the limited situation as it is today. At the same time, teachers do online learning with WA Group or with googleclassroom. But there are also those that 
combine online learning with offline. It is also in accordance with the SKB of four ministers (Minister of Health, Minister of Education, Minister of Religious Affairs, Minister of Home Affairs) (2020) stated that for areas in the yellow, orange, and red zones are not allowed to conduct face-to-face learning while in the green zone can conduct face-to-face with regard to health protocols.

The teaching materials used by teachers are using the 2013 curriculum book published by the government where the book is in a category relevant enough to imprison HOTs. One of the studies conducted by Widodo, Indraswati, Radiusman, Umar, \& Nursaptini (2020) suggested that in the student book there is a LOTS content of $36 \%$ and HOTS of $64 \%$, which means that HOTS content is higher than LOTS content. However, this 2013 curriculum book as much as possible is not the only book used in HOTS-based learning. Teachers need to develop more learning materials that can support the HOTS learning process.

Then for the learning model used, not all teachers use the learning model. Even some teachers are still unable to distinguish between learning models and learning methods. They consider blended, online, and thematically applied a learning model. However, there are some teachers who use Problem Based Learning (T1, T3, and T6) and PjBL (T11) during the online learning process. Problembased learning models are learning models that involve students working in small groups and directing them to analyze, integrate, and use problems (Sulastri1 \& Rintayati, 2019). Problem Based Learning is one of the learning models that can help students to develop HOTS thinking skill because one of HOTS is problem solving (Misykah Z. \& Adiansha, 2018). The learning process using problem based learning model trains students to develop their thinking skills and initiatives by exchanging ideas with their group friends (Suprapto \& Basri, 2017). PjBL is also effective in implementing HOTS-based learning (Suherman et al., 2020). PjBL invites students to think creatively by creating a project commissioned by the teacher.

Table 3 contains the results of data analysis and reduction from the implementation of HOTs-based learning during the Covid-19 Pandemic. The implementation of HOTs-based learning consists of activities to start the learning process, how to deliver learning materials, how students convey their findings, how teachers provide feedback, and how teachers create a pleasant learning atmosphere. The results showed that the implementation of HOTSbased learning during the Covid-19 pandemic has not been carried out to the maximum. This is seen from not all teachers start the learning process based on HOTs well which is characterized by the presence of teachers at the beginning of the learning only checking student and provide motivation in the morning then give it a task to do.

Then not all teachers in the delivery of materials refer to HOTS-based learning. This is because not all teachers create brainstorming activities in students. There are still teachers who deliver material of a teacher center while HOTS-based learning is more emphasis on the student center. Furthermore, not all teachers give students the opportunity to present their findings directly and during the learning process. Some teachers who are just waiting for the results of the work given without knowing the results given by the students are the results of their own work or not. However, during the learning process all teachers still strive to create a pleasant learning atmosphere through the application of various methods and learning media. The reduction results of each subtheme can be seen in the table below. 
Table 3. HOTs-Based Learning Process

\begin{tabular}{|c|c|c|}
\hline & Process of HOTs-based learning & Verification Result \\
\hline $\begin{array}{l}\text { Starting } \\
\text { the } \\
\text { Learning } \\
\text { Process }\end{array}$ & $\begin{array}{l}\text { - Start the learning process using simple questions as a } \\
\text { lighter to find out the students' initial knowledge and then } \\
\text { also to activate the students. (T1), (T3), (T6) } \\
\text { - The learning process begins with watching interesting } \\
\text { videos and images according to the material, then followed } \\
\text { by questions about video and images (T7), (T11), (T15) } \\
\text { - Asking questions in the form of material that has been } \\
\text { studied yesterday (T4), (T10), (T12), (T17) } \\
\text { - Express factual conditions and ask for student opinions } \\
\text { (T5) } \\
\text { - Because the learning is done online and there are } \\
\text { constraints most mobile phones brought by their parents } \\
\text { work until the afternoon so that the teacher can only give } \\
\text { any task that must be done by the student on the day. (T8), } \\
\text { (T9), } \\
\text { - Sending motivational voice notes in the classroom group as } \\
\text { a motivational generator for students to learn and then } \\
\text { deliver conventional learning materials (T2), (T13) (T16), } \\
\text { (T14) }\end{array}$ & $\begin{array}{l}\text { Not all teachers start the } \\
\text { learning process based on HOTs } \\
\text { well. It is seen that there are still } \\
\text { teachers at the beginning of the } \\
\text { learning only checking student } \\
\text { and provide motivation in the } \\
\text { morning then give it a task to do }\end{array}$ \\
\hline $\begin{array}{l}\text { How to } \\
\text { Feed } \\
\text { Materials } \\
\text { to } \\
\text { Students }\end{array}$ & $\begin{array}{l}\text { - Delivery of teaching material by providing stimulant } \\
\text { material then the learner is given the problem and analyze } \\
\text { it, then the learner expresses his opinion in order to solve } \\
\text { the problem. (T1), (T3),(T6), (T11) } \\
\text { - Delivery of materials by providing a little introduction and } \\
\text { guiding students to open teaching materials. (T2), (T4), } \\
\text { (T9), (T16) } \\
\text { - Submission of material through video according to the } \\
\text { topic is then given the opportunity to work on the problem } \\
\text { according to the material. (T5), (T10), (T12), (T14), (T15) } \\
\text { - Children are still difficult when faced with a topic and } \\
\text { looking for their own solutions and the child has not been } \\
\text { critical so the way of material feeding must always guide } \\
\text { and direct and provide fishing rods to students. (T7), (T8), } \\
\text { (T17) }\end{array}$ & $\begin{array}{l}\text { Not all teachers in material } \\
\text { delivery refer to HOTs-based } \\
\text { learning. This is seen from not } \\
\text { all teachers creating } \\
\text { brainstorming activities in } \\
\text { students. There are still teachers } \\
\text { who deliver material of a teacher } \\
\text { center while HOTS-based } \\
\text { learning is more emphasis on } \\
\text { the student center. }\end{array}$ \\
\hline $\begin{array}{l}\text { How } \\
\text { students } \\
\text { can } \\
\text { deliver } \\
\text { their } \\
\text { findings }\end{array}$ & $\begin{array}{l}\text { - Students deliver their work during learning when there is } \\
\text { face-to-face learning while online does not collect directly. } \\
\text { (T1), (T3), (T6), (T9), (T14), (T11) } \\
\text { - Students convey the results of problem solutions by } \\
\text { recording them in the notebook and then the students take } \\
\text { photos, then sent via whatsapp or google classroom and } \\
\text { collected not during the learning. (T3), (T4), (T5), (T6), } \\
\text { (T8), (T10), (T15), (T12), (T13) } \\
\text { - Delivery directly during the learning process both in } \\
\text { writing and in voice notes. (T2), (T7) }\end{array}$ & $\begin{array}{l}\text { Not all teachers give students } \\
\text { the opportunity to present their } \\
\text { findings directly and during the } \\
\text { learning process. There are still } \\
\text { some teachers who are just } \\
\text { waiting for the results of the } \\
\text { assigment without knowing the } \\
\text { results given by the students are } \\
\text { the results of their own work or } \\
\text { not. }\end{array}$ \\
\hline
\end{tabular}




\begin{tabular}{|c|c|c|}
\hline $\begin{array}{l}\text { How to } \\
\text { keep the } \\
\text { learning } \\
\text { process } \\
\text { fun }\end{array}$ & $\begin{array}{l}\text { - Given ice breaking, in the form of humor games, (T3), } \\
\text { (T4), (T11), (T12), (T13), (T14), (15), (16), (17) } \\
\text { - Giving variations in learning media. (T5), (T8), (T9) } \\
\text { - Doing a variety of models and learning methods, for } \\
\text { example today working on the problem, the next day } \\
\text { making posters, the next day games, competitions. (T1), } \\
\text { (T2), (T6), (T7), (T10), }\end{array}$ & $\begin{array}{l}\text { All teachers provide interesting } \\
\text { activities to keep motivating } \\
\text { students to learn students } \\
\text { whether it is interspersed with } \\
\text { ice breaking, variety of methods } \\
\text { and learning models }\end{array}$ \\
\hline
\end{tabular}

In the process, of HOTS-based learning during the Covid-19 pandemic has not been carried out to the maximum. This is seen from not all teachers start the learning process only record student arrivals and provide motivation in the morning then give it a task to do. Conklin (2012) suggesting that one of the things can do the teacher is opening lesson with questions that lead to HOTS with start discussions and debates. However, one of the teachers (T5) tried to start the learning process by presenting factual issues that were then discussed together in the classroom. This is useful so that students are able to criticize the information obtained (Kamarudin, Mohd, Nik, Ahmad, \& Ghani, 2017). This is in line with the opinions of Conklin (2012) that teacher can place brainstorming activities in the middle of the lesson so that students to find ideas and think creatively. They will issue their opinions, seeking answers from the superiors of the abuse obtained (Rajendran, 2008). The use of HOTS questions with contextual problems or PISA problems in the learning process was also mentioned by the teachers as one of the appropriate strategies to train for HOTS (Retnawati, Djidu, Kartianom, Apino, \& Anazifa, 2018). Then not all teachers in the delivery of materials refer to HOTS-based learning. This is because not all teachers create brainstorming activities in students. In fact, generally teachers who deliver material are teacher center compared to the student center. While one of the characteristics of HOTs-based learning is where students can exchange ideas to solve problems presented by teachers (Kamarudin et al., 2017).
Not all teachers give students the opportunity to present their findings directly and not during the learning process. Some teachers are just waiting for the results of the work given without knowing the results given by the students are the results of their own work or not. This makes the teacher not know the students' true abilities. Students only send videos or images of their work through the WA Group or googleclassroom. This cannot be blamed because of the limitations of students and teachers, both learning support facilities and teacher teaching competencies. As T14 reveals, "it is difficult to establish students' habits in thinking and writing answers and also obstacles in controlling the student's learning process online". However, during the learning process all teachers apply a variety of learning methods and learning media to create a pleasant learning atmosphere. One of them is to include ice breaking in learning.

\section{Evaluation Activities of HOTs Based Learning}

Table 4 contains the results of data analysis and reduction from HOTs-based learning evaluation activities during the Covid19 Pandemic. Evaluation of HOTs-based learning consists of how teachers conduct assessments, cognitive assessments related to HOTs assessment, assignments of home assignments. The results showed that for HOTS-based learning evasion activities are still relatively low. In addition, the authentic 
assessment process in learning is also not maximal. There are still many teachers focusing on assessing aspects of knowledge. Then for the provision of homework is not done by all teachers. Teachers who give homework also do not give tasks that lead to students' HOTS skills. The reduction results of each subtheme can be seen in the table below.

Tabel 4. Evaluation of HOTs-based learning

\begin{tabular}{|c|c|c|}
\hline \multicolumn{2}{|r|}{ Evaluation of HOTs-based learning } & Verification Result \\
\hline $\begin{array}{l}\text { How teachers } \\
\text { do assessments }\end{array}$ & $\begin{array}{l}\text { - The assessment is carried out by paying attention to } \\
\text { the attitude, skills of students, and knowledge in a } \\
\text { balanced manner. (T1), (T3), (T5), (T9), (T10), (T12), } \\
\text { (T14), (T15) } \\
\text { - As long as online focuses more on written assessment } \\
\text { (knowledge) and assessment of work made by students } \\
\text { (psychomotor). (T6), (T7), (T8), (T17) } \\
\text { - Cognitive knowledge assessment is more highlighted } \\
\text { because it feels less maximal in psychomotor and } \\
\text { affective assessment due to online learning. (T2), } \\
\text { (T13), (T11), (T16) }\end{array}$ & $\begin{array}{l}\text { Teachers generally do } \\
\text { authentic assessments. } \\
\text { However, it is more focused } \\
\text { on the knowledge aspect. As } \\
\text { for psychomotor and } \\
\text { affective is not able to assess } \\
\text { the maximum. }\end{array}$ \\
\hline $\begin{array}{l}\text { Cognitive } \\
\text { assessment of } \\
\text { HOTs } \\
\text { assessment }\end{array}$ & $\begin{array}{l}\text { - The cognitive assessments are tailored to the ability of } \\
\text { students in school so that the application of HOTs has } \\
\text { not fully occurred. (T4), (T5), (T7), (T8), (T9), (T10), } \\
\text { (T11), (T14), (T15), (T16), (T17) } \\
\text { - Don't always give questions based on HOTs (T2), } \\
\text { (T6), (T12) } \\
\text { - Always provide a description to measure students' } \\
\text { high-level thinking ability (HOTS). (T1), (T3), (T11), }\end{array}$ & $\begin{array}{l}\text { Almost all teachers have not } \\
\text { compiled cognitive } \\
\text { assessments based on HOTs. } \\
\text { This is because the } \\
\text { assessments are tailored to } \\
\text { the ability of students in } \\
\text { school and students have not } \\
\text { been accustomed to working } \\
\text { on HOTs-based questions. }\end{array}$ \\
\hline $\begin{array}{l}\text { Giving } \\
\text { homework }\end{array}$ & $\begin{array}{l}\text { - Always give tasks at home in the form of work on the } \\
\text { questions in the book, making videos, drawing, } \\
\text { making handicrafts according to the material. (T4), } \\
\text { (T6), (T7), (T9), (T11), (T12), (T13), (T14), (T15), } \\
\text { (T16) } \\
\text { - Not giving homework, because online tasks are } \\
\text { automatically done at home. (T1), (T2), (T3), (T5), } \\
\text { (T8), (T10), (T17) }\end{array}$ & $\begin{array}{l}\text { There are teachers who give } \\
\text { homework and there are } \\
\text { teachers who do not give } \\
\text { homework. Teachers who } \\
\text { give homework also do not } \\
\text { refer to students' HOTS } \\
\text { skills. }\end{array}$ \\
\hline
\end{tabular}

In this evaluation activity, teachers have conducted authentic assessments (cognitive, affective, and psychomotor). However, this authentic assessment has not been able to be done to the maximum. Many teachers are more focused on assessing aspects of knowledge alone. As for the assessment of knowledge aspects carried out only a few teachers who compiled hots-based assessment tools (T1, T3, T11). The rest of the knowledge measuring instruments compiled by teachers are still at the Low Order Thingking Skill (LOTS) stage. In addition, not all teachers give homework assignments. Based on follow-up interviews, some of them revealed that for now, the Covid-19 pandemic is only able to provide assignments. The task given is already a home 
assignment given by the teacher. The form of the given home task is also not an open-ended task. While one of the teachers can do in teaching HOTS is provide open-ended tasks as homework to find out their creativity and understanding of the lessons that they have learned (Conklin, 2012). This is example of task assigned by teacher.

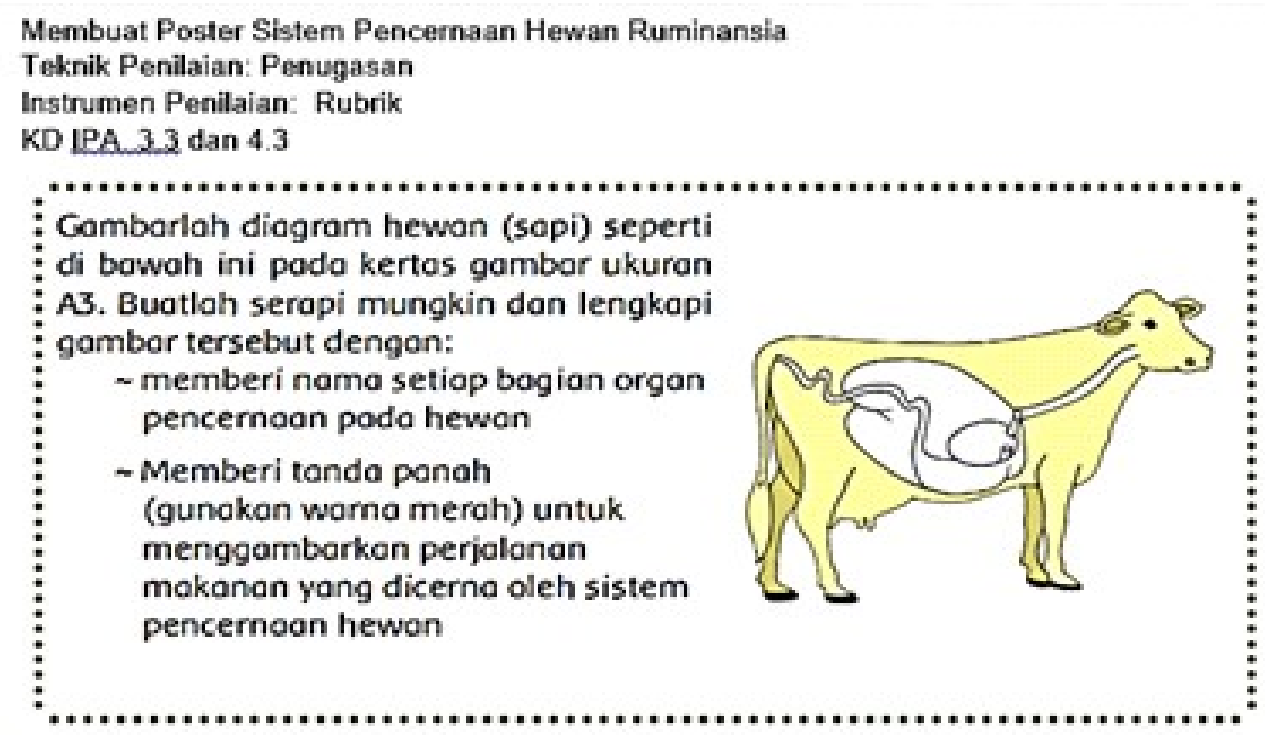

Figure 1. Examples of task assigned by teachers

\section{Barriers and Obstacles on HOTS based learning}

Table 5 contains the results of data analysis and reduction of Barriers and Obstacles on HOTS based learning during the Covid-19 Pandemic. The results showed that there are many obstacles during the learning process including the aspects of facilities and infrastructure, teacher competence and the role of parents. While in the implementation of HOTS-based learning itself teachers still experience many obstacles both from the competence of teachers in making HOTSbased questions, the ability of students who are still unfamiliar with HOTS problems, as well as situations and conditions that do not support to train HOTS-based problems. The reduction results of each subtheme can be seen in the table below.

Tabel 5. Barriers and obstacles on HOTS based learning

\begin{tabular}{|c|c|c|}
\hline \multicolumn{2}{|c|}{ Barriers and Obstacles on HOTS based learning } & \multirow{2}{*}{$\begin{array}{l}\text { Verification Result } \\
\text { There are many obstacles } \\
\text { in the form of facilities } \\
\text { and infrastructure, teacher } \\
\text { competence and the role } \\
\text { of parents. }\end{array}$} \\
\hline $\begin{array}{l}\text { Obstacles } \\
\text { During } \\
\text { learning } \\
\text { during the } \\
\text { Covid-19 } \\
\text { Pandemic }\end{array}$ & $\begin{array}{l}\text { - Problems with infrastructure, quota, internet network, } \\
\text { mobile phone ownership, mobile phone quality) (T1), } \\
\text { (T3), (T4), (T8), (T9), (T10), (T12), (T13), } \\
\text { - less able to monitor children's development and material } \\
\text { delivered is less than maximum. (T2), (T5), (T6), (T7), } \\
\text { (T10), (T11), (T14), (15), (16) } \\
\text { - Lack of attention and contribution of parents to children's } \\
\text { learning (T17) }\end{array}$ & \\
\hline
\end{tabular}




\begin{tabular}{|c|c|c|}
\hline $\begin{array}{l}\text { Teacher } \\
\text { barriers in } \\
\text { preparing } \\
\text { HOTs-based } \\
\text { assessments } \\
\text { during the } \\
\text { Covid-19 } \\
\text { pandemic }\end{array}$ & $\begin{array}{l}\text { - Some students still have not mastered basic skills } \\
\text { (observing, understanding, reasoning) and have not been } \\
\text { able to be invited to think at a high level. (T2), (T4), (T5), } \\
\text { (T7), (T9), (T8), (T12), (T14), (T15) } \\
\text { - The teacher has not yet mastered the assessment of } \\
\text { HOTS. Still confused with the learning model that must } \\
\text { be used to fit HOTS-based learning especially for } \\
\text { mathematics and science learning that must require face- } \\
\text { to-face. (T1), (T3), (T6), (T10), (T11), (T12) Takes a long } \\
\text { time in designing problem shapes. (T13), (T16), (T17). }\end{array}$ & $\begin{array}{l}\text { Teachers are still } \\
\text { experiencing many } \\
\text { obstacles both from } \\
\text { teacher competence in } \\
\text { making HOTs-based } \\
\text { questions, the ability of } \\
\text { students who are still } \\
\text { unfamiliar with HOTs, as } \\
\text { well as situations and } \\
\text { conditions that do not } \\
\text { support to train HOTs- } \\
\text { based problems. }\end{array}$ \\
\hline
\end{tabular}

The implementation of learning during the Covid-19 pandemic has indeed become disrupted. Many obstacles faced by students and teachers are online learning. Starting from inadequate facilities and infrastructure (i.e internet quota, mobile phones, difficult internet networks), the role of parents, to the competence of digital literacy and creativity owned by teachers. As revealed by T4, "I am still confused about the learning model that should be used especially for mathematics and science learning that must require faceto-face. While face-to-face for 1 hour in school we felt very less than 6. I am confused which media to use for learning". Just as revealed by Purwanto et al (2020) that online learning in one of these elementary schools gives many obstacles both to students, teachers and parents. Moreover, considering the level of elementary school children are still at the stage of learning while playing and the stage of character formation. It also affects the implementation of HOTS-based learning.

In addition, the constraints mentioned above are in the implementation of teacher HOTs-based learning still experiencing many obstacles both from teacher competence in making HOTs-based questions, the ability of students who are still unfamiliar with HOTS problems, as well as situations and conditions that do not support to practice HOTS-based problems. But actually in this case the more important thing is the competence of teachers in shaping the learning process based on HOTS. This can be seen from the way teachers 1) use learning strategies, methods and techniques of learning; 2) preparation of assessment, and 3) management of learning environment (Misykah Z. \& Adiansha, 2018). As for the students themselves, it is actually following the activities planned by the teacher. Therefore, the role of the government is also needed to improve the socialization and training of HOTS-based learning that is expected.

\section{CONCLUSION}

The results of this study show that teachers' knowledge about HOTS-based learning is quite good. Even teachers already understand that the importance of HOTS-based learning in the face of $21 \mathrm{st}$ century learning. However, in implementing it, teachers still find it difficult. In addition, the learning situation has changed due to Covid-19. This is seen from the planning, implementation and evaluation carried out by teachers during learning during the Covid-19 Pandemic. In the planning, teachers have not used media and learning models that refer to students' HOTS skills the teaching materials used also only refer to the student's HOTS which is the 2013 curriculum student book and make the only guidelines in learning. In addition 
to the process and evaluation activities of learning, teachers are also not maximal in implementing HOTS-based learning. Some of the learnings implemented become more teacher center by assigning less supportive tasks on HOTS skills.

HOTs-based learning during the Covid19 pandemic has become unable to be done to the maximum due to the limitations of students and teachers in the learning process. This is seen from several aspects, namely the infrastructure, students' ability, the role of parents and the ability of teachers in implementing HOTs-based learning. In addition, the characteristics of elementary school students who are more likely to be happy to play are also an obstacle for students to be able to learn independently. This is undeniable because for the application of HOTs-based learning in normal life alone can not be maximum especially for the situation of the Covid-19 Pandemic that is all limited as it is today. Therefore, further researchers hope to develop media that can help or provide innovation ideas for teachers in the learning process based on HOTs during the Covid-19 Pandemic. In addition, it is necessary for further researchers to examine what learning models would be suitable to support HOTs-based learning processes during the Covid-19 Pandemic.

\section{REFERENCES}

Afifah, I. R. N., \& Retnawati, H. (2019). Is it difficult to teach higher order thinking skills? Journal of Physics: Conference Series, 1320.

Anderson L. W. and Krathwohl D. R. (2001). A taxonomy for learning, teaching, and assessing/: A revision of Bloom's Taxonomy of educational objectives. Newyork: Longman.

Anggraeni, D. M., \& Sole, F. B. (2020). Analysis of Science Teachers' Understanding of
High Order Thinking Skills (HOTS) and Their Implementation in Learning. Jurnal Penelitian Pendidikan IPA, 6, 210.

Cer, E. (2018). A comparison of mother-tongue curricula of successful countries in PISA and Turkey by higher-order thinking processes. Egitim Arastirmalari Eurasian Journal of Educational Research, 2018, 95-112.

Conklin, W. (2012). Higher order thinking skills to develop 21st century learners. Huntington Beach, CA: Shell Education Publishing.

Fadel, C. (2008). How can you prepare students for the new Global Economy? Oecd/Ceri, $1-22$.

Hassan, S. R., Rosli, R., \& Zakaria, E. (2016). The Use of i-Think Map and Questioning to Promote Higher-Order Thinking Skills in Mathematics. Creative Education, 07, 1069-1078.

Indah, P. (2020). Development of HOTS (High Order Thinking Skill) Oriented Learning Through Discovery Learning Model to Increase The Critical Thinking Skill of High School Students. International Journal of Chemistry Education Research, 3.

Kamarudin, M. Y., Mohd, N., Nik, R., Ahmad, H. Y., \& Ghani, K. A. (2017). Inculcation of Higher Order Thinking Skills ( HOTS ) in Arabic Language Teaching at Malaysian Primary Schools. Scientific Research Publishing Inc.

Kesehatan, M., Pendidikan, M., Negeri, M. D., \& Menteri Agama. (2020). Panduan Penyelenggraan Pembelajaran Pada Tahun Ajaran 2020/2021 dan Tahun Akademik 2020/2021 di Masa Pandemi Corona Virus Disease 2019 (Covid-19). 2019.

Misykah Z., \&Adiansha, A.A. (2018). Effective teaching for increase higher-order thinking skills ( hots ) in education of elementary 
school. International Conference on Mathematics and Science Education, 3, 658-664.

Mubarok, H., Suprapto, N., \& Adam, A. S. (2019). Using Inquiry-Based Laboratory to improve students' Higher Order Thinking Skills (HOTs). Journal of Physics: Conference Series, 1171.

Permendikbud Nomor 22 Tahun 2016.(2016). 9, 10.

Purwanto, A., Pramono, R., Asbari, M., Santoso, P. B., Wijayanti, L. M., Choi, C. H., \& Putri, R. S. (2020). Studi Eksploratif Dampak Pandemi COVID-19 Terhadap Proses Pembelajaran Online di Sekolah Dasar [Explorative Study of the Impact of the COVID-19 Pandemic on Online Learning Process in Elementary Schools]. EduPsyCouns: Journal of Education, Psychology and Counseling, 2, 1-12.

Rahayu, G. D. S., Altaftazani, D. H., Kelana, J. B., Firdaus, A. R., \& Fauzi, M. R. (2020). Analysis of elementary school students' mathematical resilience during learning during the COVID 19 Pandemic. Journal of Physics: Conference Series, 1657.

Rajendra, N. S. (2008). Teaching \& Acquiring Higher Order Thinking: Theory and Practice. Tanjong Malim: Universiti Pendidikan Sultan Idris.

Ramdiah, S., Abidinsyah, Royani, M., \& Husamah. (2019). Understanding, planning, and implementation of HOTS by senior high school biology teachers in Banjarmasin-Indonesia. International Journal of Instruction, 12, 425-440.

Retnawati, H. (2016). Hambatan Guru Matematika Sekolah Menengah Pertama Dalam Menerapkan Kurikulum Baru [Barriers for Junior High School Math Teachers in Implementing New Curriculum] Jurnal Cakrawala Pendidikan, 3, 390-403.
Retnawati, H., Djidu, H., Kartianom, Apino, E., \& Anazifa, R. D. (2018). Teachers' knowledge about higher-order thinking skills and its learning strategy. Problems of Education in the 21st Century, 76, 215-230.

Riandari, F., Susanti, R., \& Suratmi. (2018). The influence of discovery learning model application to the higher order thinking skills student of Srijaya Negara Senior High School Palembang on the animal kingdom subject matter. Journal of Physics: Conference Series, 1022. https://doi.org/ 10.1088/1742-6596/1022/1/012055

Saputra, H. (2016). Pengembangan Mutu Pendidikan Menuju Era Global. Bandung: CV Smile's Indonesia Institute. Sofyan, F. A., \& Fihtanti, A. I. (2019). Implementasi Hots Pada Pembelajaran Matematika SD/MI Kelas 6 [Implementation of HOTS in Mathematics Learning SD/MI Grade 6]. Jurnal Guru Kita, 4, 18-26.

Suherman, Prananda, M. R., Proboningrum, D. I., Pratama, E. R., Laksono, P., \& Amiruddin. (2020). Improving Higher Order Thinking Skills (HOTS) with Project Based Learning (PjBL) Model Assisted by Geogebra. Journal of Physics: Conference Series, 1467.

Sulastri', K., \& Rintayati, P. (2019). Improving Higher Order Thinking Skills and Students ' Learning Interest through Problem-Based Learning Model on Literacy. Third International Conference of Arts, Language and Culture, 279, 346-352.

Suntrock, J. W. (2011). Psikologi Pendidikan. Edisi 3. Dterjemahkan oleh: Angelica. Jakarta: Salemba Humanika.

Suprapto, E., \& Basri, K. (2017). The Application of Problem-Based Learning Strategy to Increase High Order Thinking Skills of Senior Vocational School 
Students. International Education Studies, 10, 123-129.

Suryabrata, S. (2015). Psikologi Pendidikan. Jakarta: PT RajaGrafindo Persada.

Susilo, A., Rumende, C. M., Pitoyo, C. W., Santoso, W. D., Yulianti, M., Sinto, R., ... Cipto, R. (2020). Coronavirus Disease 2019/: Tinjauan Literatur Terkini (Coronavirus Disease 2019/: Review of Current Literatures). 7, 45-67.

Wall, T. F. (2015). The Transferability of Higher Order Cognitive Skills. Procedia - Social and Behavioral Sciences, 174, 233-238.

Widodo, A., Indraswati, D., Radiusman, R., Umar, U., \& Nursaptini, N. (2020). Analisis Konten HOTS dalam Buku Siswa Kelas V Tema 6 "Panas dan Perpindahannya” Kurikulum 2013 [Analysis of HOTS Content in Grade V Student Book Theme 6 "Heat and
Displacement" Curriculum 2013]. Madrasah: Jurnal Pendidikan dan Pembelajaran Dasar, 12, 1-13.

Yee, M. H., Yunos, J. M., Othman, W., Hassan, R., Tee, T. K., \& Mohamad, M. M. (2015). Disparity of Learning Styles and Higher Order Thinking Skills among Technical Students. Procedia - Social and Behavioral Sciences, 204, 143-152.

Yuliana. (2020). Corona Virus Diseases: Sebuah Tinjauan Literatur [Corona Virus Diseases: A Literature Review] . Wellness and Healthy Megazine, 2, 124 137.

Yulianto, T., Pramudya, I., \& Slameet, I. (2019). Effects of the 21st Century Learning Model and Problem-Based Models on Higher Order Thinking Skill. International Journal of Educational Research Review, 4, 749-755. 